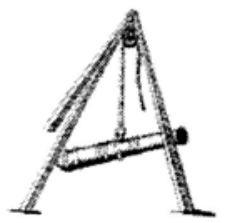

\title{
The Crocodile Strikes Back: Saint Martin's Interpretation of the French Revolution
}

\author{
Fabienne Moore
}

\begin{abstract}
Les guerres humaines où on a le plus parlé de religion sont celles où la religion était le plus étrangère; aussi les guerres et les massacres innombrables de l'Islamisme, quoiqu'étant une esquisse des guerres religieuses, se bornoient à détruire et ne bâtissaient point; aussi nos guerres des croisades et de la ligue, celles du luthéranisme et celles du schisme d'Angleterre, quoique se faisant toutes au nom de la religion, n'étaient que des guerres d'hypocrisie; et en fait de religion, elles ne détruisaient ni ne bâtissaient: au lieu que la guerre actuelle, toute matérielle et humaine qu'elle puisse paraître aux yeux ordinaires, ne se borne point à des démolitions, et elle ne fait pas un pas qu'elle ne bâtisse.- - LouisClaude de Saint-Martin, Lettre à un ami ... sur la Révolution française.'
\end{abstract}

\begin{abstract}
A few weeks after 11 September 2001, French philosopher Jean to understand wrote in Le Monde that terrorism was forcing people evil on "le contresenferently. He blamed our misapprehension of total de la philosophie occidentale, celle des Lumières." According to Baudrillard, the optimism inherited from the Enlightenment has skewed our perception of evil as a mere accident, a contingency. Therefore, "nous croyons naïvement que le progrès du Bien, sa montée en puissance dans tous les domaines

1 Louis-Claude de Saint-Martin, Lettre à un ami, ou considérations politiques, philosophiques et religieuses sur la Révolution française (An III [1796]), in Controverse avec Garat précédé d'autres écrits philosophiques, ed. Robert Amadou (Paris: Fayard, 1990), 64. References are to this edition. Unless otherwise noted, all translations are my own.
\end{abstract}


(sciences, techniques, démocraties, droits de l'homme) correspond à une défaite du Mal. Personne ne semble avoir compris que le Bien et le Mal monte en puissance en même temps, et selon un même mouvement." I think Baudrillard downplays the complexities of the Enlightenment by equating its advocacy of progress and reason with uncritical and unflinching triumphalism. An examination of how Voltaire agonized about the question of evil in the wake of the Lisbon earthquake, and went on to confront his optimist contemporaries with Candide's travails, reveals that the philosophes did not all forsake their esprit critique for a metaphysics of optimism when they faced the question of evil. Yet Baudrillard's generalization rings true as a common, global perception of the Enlightenment as a positive and positivist philosophy. This perception was shared by the thinkers, writers, and readers of the eighteenth century-keeping at bay Rousseau's pessimism-as well as the revolutionaries who acted as agents of progress and change. The critique of evil was enfolded into a discourse of rationality, establishing differences between natural catastrophes and manmade disasters (slavery, the Inquisition, wars), deeming the latter curable evils. In this article I introduce a (selfdescribed) "philosophe inconnu," Louis-Claude de Saint-Martin (1743-1803), ${ }^{3}$ who, though an optimist by faith, offered his contemporaries an allegory on the battle between Good and Evil that was and remains a prescient warning on their intertwining. Poised at the junction between the Revolution and the Terror, as the shift had not quite yet shocked pro-revolutionaries like himself, the author struggles to invent a genre-an allegorical prose poem-to represent and interpret one of the most drastic turns in French history.

Saint-Martin's choice of form-allegory-reflects a solidarity with the historical period that the allegory evokes and during which it was written (at the turn of the 1789 Revolution into the 1793-94 Terror). To understand what might have motivated this allegory, we need to look both at the role and meaning of allegory as a rhetorical figure, and at the role and meaning of the Revolution according to SaintMartin. The characteristics unique to allegory (soon to be disparaged by the Romantics in favour of the symbol) made it the most suitable expression of reason's struggle to make sense of this overwhelming historical moment. Saint-Martin's text promotes the relevance and

2 Jean Baudrillard, "L'Esprit du terrorisme," Le Monde, 3 November 2001.

3 See primary and secondary sources as well as illustrations on a website ded Martin's life, work, and influence: http://ll as illustrations on a website dedicated to Saint. 
usefulness of allegory to represent events such as wars and uprisings. This valorization runs counter to our still Romantic preference for symbols and metaphors, yet it might offer a solution germane to the "writing of disaster" examined by critics such as Maurice Blanchot. Saint-Martin's imperfect work of fiction verifies Blanchot's aphorism: "Quand tout est dit, ce qui reste à dire est le désastre, ruine de parole, défaillance par l'écriture, rumeur qui murmure: ce qui reste sans reste (le fragmentaire)." That Saint-Martin chose an allegory to write on evil, war, terror, disaster, and overcoming them invites us to examine anew this rhetorical trope: a baroque impulse to confront history's facies hippocratica-its death's head-as Walter Benjamin proposed, as much as a signifier of fractured modernity challenging the unity of symbols as Paul de Man argued, Saint-Martin's allegory of the Revolution signifies demolition while trying to project construction. ${ }^{5}$

The epigraph encapsulates Saint-Martin's constructive reading of the French Revolution, celebrated as the "current" religious war. In 1796, Saint-Martin published this "profession de foi" (48), whose echo reaches us in the midst of our contemporary struggle with values, religion, and war, as a Lettre à un ami, ou Considérations politiques, philosophiques et religieuses sur la Révolution française, a meditation about a still ongoing crisis. In it, he explains to an unnamed friend that the French Revolution was not simply an ordinary and human war, but essentially a religious or a divine war-the second religious war to date experienced by humanity since "la guerre des Hébreux qui a duré pour ainsi dire depuis Moyse jusqu'à Titus” $(63,64)$. Indeed, all other supposedly religious wars in history did not deserve to be labelled as such because they were either simply destructive (Islamic wars) or falsely constructive (European wars of religion), whereas the French Revolution, if it wrought destruction, also built anew, which was the single measure of a sacred war in Saint-Martin's opinion.

Saint-Martin's life and work are not well known today, though his writing played a considerable role before and after the Revolution, including his sharp critique of the Enlightenment philosophes. ${ }^{6} \mathrm{His}$ mysticism later inspired numerous Romantic authors throughout

4 Maurice Blanchot, L'Écriture du désastre (Paris: Gallimard, 1980), 58.

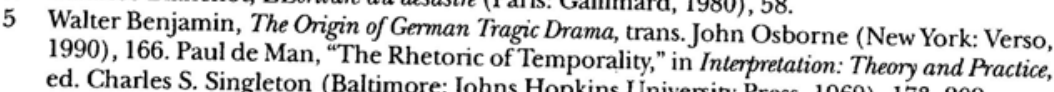

6 On Saint-Martin's influence (Baltimore: Johns Hopkins University Press, 1969), 173-209.

Sources occultes $d u$ Romance over the birth of French Romanticism, see Auguste Viatte, Les Sources occultes du Romantisme. Illuminisme, théosophie. 1770-1820. Tome 1 Le Préromantisme (Paris: Champion, 1979); and Paul Bénichou, Le Sacre de l'écrivain: Essai sur l'avènement d'un pouvoir spirituel laique dans la France moderne (Paris: Corti, 1973). 
Europe. ${ }^{7}$ Saint-Martin belonged to the generation who turned a page of history as it witnessed the end of the Ancien Régime and survived revolutionary turmoil ${ }^{8} \mathrm{His}$ was the rare case of an aristocrat who lost his fortune but saved his head, genuinely embracing the Revolution as revealed by his Lettre $\grave{a}$ un ami, an extraordinary anti-clerical document vindicating the revolutionaries for having eliminated the "gangrène" of aristocrats and priests. ${ }^{9}$ Simultaneously, SaintMartin wrote his only work of fiction about the Revolution, a sprawling allegory quickly exiled from the canon: Le Crocodile, ou la guerre du bien et du mal arrivée sous le règne de Louis $\mathrm{XV}$, composed in $1792 .{ }^{10}$ Waiting until 1799 to publish it, he wrote an anonymous article praising his own fiction as "un ouvrage extraordinaire dans lequel l'auteur, sous le voile d'une allégorie toujours soutenue, développe des vérités très hautes, et jette ça et là les germes d'une philosophie absolument neuve, ou qui du moins n'a été connue jusqu'à présent que d'un bien petit nombre de personnes."11 This mysterious philosophy is "illuminisme," based on divine revelation and the search for spiritual regeneration.

7 At Coppet, Germaine de Staël opened herself to German philosophy and mysticism, adopting Saint-Martin's definition of religion as "lumière des lumières." See Brian Juden, Traditions orphiques et tendances mystiques dans le romantisme français, 1800-1855 (1971; Geneva: Slatsocialisme (1852) and 174. Gérard Nerval wrote an essay on Les Illuminés, ou les précurseurs du socialisme (1852) and infused his writings with illuminist notions. The author of the Comédie in his first noveré de Balzac, immersed himself in Saint-Martin's ideas and featured them in his first novel, Le Lys dans la vallée, as well as in Séraphîta. See Maurice Roche, Balzac et Martin directly, applies the : Gibert-Clarey, 1951). Baudelaire, although never citing SaintMarie Amiocty, applies the principles of his new poetics governed by spiritualism. See Anneet les poëmes en prose et lilluminisme (Paris: Nizet, 1982); and Fabienne Moore, "Baudelaire of European authors du dix-huitième siècle," Bulletin Baudelainien (January 2006). For a list Nicole Jacques-Lefèvre and readers, with quotations referring to Saint-Martin's thought, see tion," at http://www philos Antoine Faivre, "Saint-Martin et ses lecteurs: histoire d'une recep-

8 For more details on Saint-Martin's life,com/Etudes/Reception-sm/reception_01.htm. Robert Amadou (Paris: Julliard, 1961); see his Mon Portrait historique et philosophique, ed. le Philosophe inconnu," Cau, 1961); and Charles Augustin Sainte-Beuve, "Saint-Martin, under the Revolution, "Causeries du lundi, tome 10 (1855), 190-225. On his behaviour under the Revolution, see Mieczyslawa Sekrecka, Louis-Claude de Saint-Martin, le philosophe inconnu. L'homme et l'auvre (Wroclaw: Acta Universitatis Wratislaviensis, no. 59, 1968), 16173. For recent work on Saint-Martin, see Jacques-Lefèvre, Louis-Claude de Saint-Martin, le philosophe inconnu (1743-1803). Un Illuministe au siècle des Lumières (Paris: Dervy, 2003).

10 Saint-Martin, Le Crocodile, ou la guerre du bien et du mal arrivée sous le règne de Louis XV, poème épico-magique en 102 chants, ed. Simone Rihouët-Coroze, pref. Robert Amadou (1799; Paris: Triades-Editions, 1979). References are to this edition. Unless otherwise noted, all transla-

Ce Crocodile more penetrable than his ile, 15. Saint-Martin considered the allegorical veil of laisse entrevoire penetrable than his earlier writings: "Quelques écrits ont déjà paru, où on laisse entrevoir sous des voiles, toujours mystérieux il est vrai, les principes et les bases de cette science. Ici, les voiles subsistent encore, mais cependant plus faciles à pénétrer" (16). 
The Encyclopédie's philosophers and the fin-de-siècle ideologues worked under the aegis of "les Lumières." The metaphor of light stood for human reason and intelligence penetrating experience to reveal our universe. For proponents of "illuminisme," light came from above as an illumination, namely a divine, supernatural light. ${ }^{12}$ SaintMartin, the most outspoken disseminator of "illuminisme," devoted his life to the study of humanity, appearing in many ways a humanist in the tradition of the preceding century. Yet France's "Philosophe inconnu," the pseudonym under which Saint-Martin published his writings, thrust open the doors left ajar by such humanists turned quietist as Fénelon, ${ }^{13}$ advancing and developing the mystical writings of Martinès de Pasqually (1710?-1774), the Swedish author Swedenbörg (1688-1772), and most importantly, the German Jacob Boehme (1575-1624). ${ }^{14}$ Around 1754, Pasqually founded the order of “Chevaliers Maçons Élus coëns de l'Univers," into which Saint-Martin was initiated in 1765, later becoming Pasqually's secretary. From the beginning Saint-Martin expressed scepticism about the complex and mysterious Masonic rituals, preferring to focus instead on Pasqually's theoretical teachings and his Kabbala-inspired interpretation of the Old Testament. As Nicole Jacques-Lefèvre points out, Saint-Martin not only absorbed but also "transmuted" his mentor's theurgy "en une théorie de l'action de l'homme sur lui-même et sur le monde, et en une théorie de l'écriture, et plus particulièrement de l'écriture poétique." 15 Saint-Martin's own original perspective rested on temporality and interiority. In opposition to the timelessness of Pasqually's Masonic initiation rites, insulated from historical flux, Martinist theosophy "tien[t] compte, dans l'optique même de son efficacité, des données particulières du siècle où elle se construit." ${ }^{16}$ Moreover, Saint-Martin

12 Roland Mortier traced the origins of the metaphor of light in "Lumière et Lumières: Histoire d'une image et d'une idée au xvire et au xvire siècle," in Clartéset ombres du siècle des Lumières. Etudes sur le xnIr siècle littéraire (Genève Droz, 1969), 13-59.

13 Fénelon (1651-1715) was inspired by Jeanne-Marie Guyon (1648-1717), whose best-known work is Le Moyen court et très facile de faire oraison que tous peuvent pratiquer très aisément et arriver par là dans peu de temps à une haute perfection (1682).

14 Saint-Martin was critical of Swedenbörg for offering his own visions as proof of a divine principle. See L'Homme de désir (1790; Monaco: Éditions du Rocher, 1994), stanza 184, pp. 215-16. In this article, I will not deal with the respective influence of these three authors on the development of Saint-Martin's thought, a complex subject examined particularly by Amadou and Sekrecka. For a brief overview of the heritage of Martinès de Pasqually and

15 Jacques-Lefèvre, Louis-Claude de Saint-Martin, 29.

16 Jacques-Lefèvre, Louis-Claude de Saint-Martin, 29. 
shunned miraculous operations, prodigies, and other marvellous communications (as showcased by Cagliostro and Mesmer), to turn inward, relying on will and desire to reach spiritual knowledge-an inner course in keeping with Boehme's teachings. Saint-Martin turned his attention away from external "magical" demonstrations to observe instead history's upheavals. To the tempting gratification of a symbolic union with the eternal promised by esoteric practices, he preferred the more arduous quest for meaning: in his quest to reach spiritual enlightenment, "allegorèse" prevailed over symbolism, prefiguring the same shift in his writing.

Saint-Martin the theosophist has been overshadowed by the ideologues, his contemporaries in the last quarter of the eighteenth century: then and now his mysticism challenges the nature of modernity and progress associated with the Enlightenment and the Revolution. ${ }^{17}$ In a recent essay, Paula McDowell concludes that "we still lack any detailed synthetic study of the development and continuity of enthusiastic religious movements and writings over the course of the long eighteenth century, and accordingly, only further research will reveal whether the Philadelphians really 'failed'-or whether ... they served as important carriers of an underground intellectual tradition that extends from Boehme to Blake." ${ }^{18}$ European Enlightenment's "other side," whether qualified as occult, enthusiastic, mystical, or theosophical, calls for renewed interpretation. As McDowell points out, although these inspired, spiritualist discourses exerted considerable influence throughout Europe, they now generate critical discomfort: not only are visionary writings perceived as antithetical to the Age of Reason but they also appear too esoteric to warrant serious academic investigation. ${ }^{19}$

I will concentrate on the two texts that Saint-Martin devoted exclusively to the French Revolution, the Lettre à un ami excerpted in the epigraph, and Le Crocodile. Together, these intriguing documents present an original tableau of the revolutionary upheaval, a disturbing

17 Unlike the French Enlightenment, the German Aufklarung was not hostile to religion, offering a compromise between philosophy and theology (see Moses Mendelssohn, Schreiben an den Herrn Diaconus Lavater zu Zürich [Berlin and Leipzig, 1770], and Johann
Gottfried von Herder, Zwei Preisschriften [Berlin, 1789]).

18 Paula McDowell, "Enlightenment Enthusiasms and the Spectacular Failure of the Philadelphian Society," Eighteenth Century Studies 35, no. 4 (Summer 2002), 528.

19 For exceptions, see Margaret Jacob, The Radical Enlightenment: Pantheists, Freemasons, and Republicans (London; Boston: Allen and Unwin, 1981); and Jonathan Irvine Israel, Radical Enlightenment: Philosophy and the Making of Modernity, 1650-1750 (Oxford and New York:
Oxford University Press, 2001). 
accusation of irresponsible religious and academic institutions, puzzling in its mélange of serious and humorous tones, and ultimately presenting a Revolution "en contre-jour," to reveal a new transcendental paradigm.

\section{Lettre à un ami}

Saint-Martin had already achieved notoriety with his first treatise, Des Erreurs et de la vérité (1775), a condemnation of the erroneous practices of the Church, and of the philosophers propagating materialism and sensualism, a first book that became, after his death, the target of accusations that it played a role in fomenting the Revolution. ${ }^{20}$ Saint-Martin's actions during the Revolution contrasted with his (as yet unknown) young contemporary Chateaubriand, who quickly emigrated. ${ }^{21}$ In 1789, Saint-Martin lived in Strasbourg, immersed in his study of Boehme, therefore not an eyewitness to the Revolution's outbreak. His "petite noblesse" origins made him a target for measures decreed against aristocrats, which included opened mail, loss of his six-thousand-livres pension, ${ }^{22}$ seizure of his Parisian hotel lodgings, and exile to his native Amboise. ${ }^{23}$ There, he conscientiously volunteered his help and donated money as a patriot at the service of the Revolution and the newly proclaimed Republic. Saint-Martin's quiet confidence during the violent, chaotic crisis is surprising and unusual: unfazed by the momentous historical events unfolding, he never felt the need to resist, hide, or emigrate. The most revealing episode occurred on the now famous "journée" of 10 August 1792, when armed insurgent crowds took over the Tuileries, Louis xv's residence, leading the deputies to suspend the king, who had taken refuge in the Assembly. On that day, when the street pronounced

20 See Sekrecka, 182-83.

21 Marc Fumaroli maintains that the Terror condemned Chateaubriand not only to exile but also to prose. Notwithstanding their political divergence, Chateaubriand and Saint-Martin faced the same aesthetic fallout: the inadequacy of conventional verse to capture and convey their prophetic voice, the challenge not to let (the) Terror inhibit poetry. Fumaroli, Chateaubriand. Poésie et Terreur (Paris: Fallois, 2003), 16.

22 "Quoique ma fortune souffre beaucoup de la Révolution, je n'en persiste pas moins dans mon opinion sur les propriétés;j'y peux comprendre particulièrement les rentes. Rien n'est plus éloigné de la racine que cet usage abusif du signe représentatif de la propriété; aussi je le trouve bien plus faux que la propriété même. Tous nos profits, tous nos revenus, devraient être le fruit de notre travail et de nos talents; et ce renversement des fortunes opéré par notre Révolution nous rapproche de cet état naturel et vrai, en forçant tant de monde à mettre en activité leur savoir-faire et leur industrie." Saint-Martin, Mon Portrait, 303.
Saint-Martin, Mon Portrait, 230. 
"la fin de la royauté,"24 Saint-Martin managed to walk across Paris unharmed-a safe passage he credited to Providence watching over him. In his Lettre à un ami, Saint-Martin interpreted the astonishing revolution as a manifestation of a Providence involved either directly or indirectly $(47,58)$. The revolutionary war only seemed human from an external impression of tumultuous and violent passions, while a hidden, wrathful hand had guided events by design $(63,59)$. The swift succession of these events, together with a French national character antithetic to such masterful planning, justified for SaintMartin the comparison with "une sorte de féerie ... une opération magique" (58). From the beginning of the letter to his friend, SaintMartin ascribed to the equitable hand of Providence the destruction of abuses, none so outrageous as those perpetrated by the clergy, which held the first rank in terms of ambition and "sacrilèges malversations" (47). Priests were not only the most guilty but also "les seuls auteurs de tous les torts et de tous les crimes des autres ordres" (59). Saint-Martin assigned the harshest blame to the clergy on account of its corrupted duties: "c'est le clergé qui est la cause indirecte des crimes des Rois, parce que c'est le prêtre qui ... s'est arrogé le droit d'instituer et de destituer les Rois, de les consacrer, et de légitimer ensuite tous leurs écarts et tous leurs caprices" (59). Priests had turned their rights into "une despotique dévastation et un règne impérieux sur les consciences." If the destruction of the clergy was salutary, the fall of the king was beneficial too, in the lesson it taught mistaken rulers and courtiers "[qui] concentrent toute une nation dans un seul homme et dans ceux qui peuvent tenir à lui" (62). One senses already how counter-intuitive Saint-Martin's ideas and behaviour were: not only a radical Rousseauist, an aristocrat vocal against privileges, an anti-clerical Christian, and an optimist in the face of the Terror, but also a pro-revolutionary unlike any other, since he fought against the philosophical movement that propelled the changes he welcomed. ${ }^{25}$

Enemies abounded, therefore, in those who failed to see "quel est le mobile de notre surprenante révolution qui peut s'appeler la révolution du genre humain." Saint-Martin's double goal was to search for the causes of the Revolution while denouncing the blindness and obtuseness of "our enemies" who found pretexts to account for

24 François Furet, La Révolution (Paris: Hachette, 1988), 196.

25 On his divergence with Jean-Jacques Rousseau, whom he admired as "un prophète de l'ordre sensible," see Saint-Martin, Lettre à un ami, 78-79; and Mon Portrait, 70, 217, 219. 
the impetus behind the conflict, thereby denying Providence. Two such pretexts, according to Saint-Martin, were political and social (64). The enemy philosophers (whom he called "les publicistes") had remained at the surface of things, too focused on forms (governmental, social) to understand core principles, which Saint-Martin metaphorized as "les racines sacrées et immortelles, sur lesquelles seules ... doive reposer l'arbre social": wisdom, justice, and strength, the respective foundations of natural, civil, and political society (97, 95). The philosophers' analyses remained superficial and unproductive: "ils se sont attachés à mettre à découvert nos plaies sociales, et ensuite, au lieu d'injecter la vie jusques dans les racines de l'association humaine, comme je tâche d'y contribuer, par les principes vivants que je t'expose, ils ont arrêté leurs regards sur l'épiderme du malade" (99-100). The letter ends with the visionary conviction that the "marche imposante de notre majestueuse revolution" is the execution of Providence's decree encrypted in fire-a last judgment (117). Saint-Martin called for courage in withstanding pain following a spiritual surgery to remove the "corps étranger," and for patience in nursing physical and social wounds, for health would soon return, man's sublime nature would be recovered, and a pure religion would be born (117). This constructive interpretation of the Revolution, also evident in this article's epigraph, differentiates Saint-Martin's "apocalypse positive" from the "apocalypse negative" of Joseph De Maistre, the better-known counter-revolutionary and providentialist theorist, with whom Saint-Martin is often mistakenly united. ${ }^{26}$

As Jacques-Lefèvre argues, if the Revolution signalled the beginning of a new era for Saint-Martin, "cet optimisme est en même temps, et non contradictoirement, tragique. L'homme et l'univers sont, depuis la Chute, inscrits dans un devenir violemment dramatique, marqué par des 'crises' successives, fructueuses, mais brutales. Et le travail de la régénération se différencie nettement de la croyance béate en un progrès inéluctable." ${ }^{27}$ The same "tragic optimism" based on hopeful overcoming of man's present fallen state pervades

26 For a discussion of the differences between Saint-Martin and De Maistre, see Erica Joy Mannucci, "La Révolution comme apocalypse positive (Saint-Martin) et comme apocalypse négative (De Maistre)," in L'Image de la Révolution française. Communications présentées lors du Congrès mondial pour le Bicentenaire de la Révolution. Sorbonne Paris, 6-12 juillet 1989, ed. Michel Vovelle, 4 vols. (Paris: Pergamon Press, 1990), 3:2046-54.

27 Jacques-Chaquin [Jacques-Lefèvre], "Illuminisme et théosophie," in Dictionnaire européen des Lumières, ed. Michel Delon (Paris: PUf, 1997), 570-73. See also Jean Roussel, "Le regard de L.C. de Saint-Martin sur l'histoire," in Présence de Louis-Claude de Saint-Martin (Paris: L'Autre
Rive, 1986), 291-304. 
Le Crocodile, wherein religious, philosophical, and literary complexity defies interpretation.

\section{Le Crocodile}

The subtitle of Le Crocodile subverts any appropriation based on genre-it is a "poème épico-magique en 102 chants"-and the pseudonym, "par un amateur de choses cachées," points to the esoteric, secret design behind the burlesque appearance of the evil crocodile. Le Crocodile, ou la guerre du bien et du mal arrivée sous le règne de Louis XV is a mock-heroic poem in prose. While it continuously plays with literary conventions through mystifying and witty stylistic and thematic parodies, it also directly engages a dangerous subject. The story allegorized the Revolution at a time when most contemporaries shied away from fictionalizing its traumatic violence. Le Crocodile raised a few eyebrows but otherwise failed to attract notice or praise. It was too extravagant, and the narrative and didactic episodes were too repetitive and roughly stitched together. Saint-Martin himself admitted it would have benefited from tighter editing. ${ }^{28}$ Midway between the fantastic novel and romantic epic poetry, "sa situation dans l'histoire de la littérature reste à déterminer." ${ }^{29}$ How does a sweeping allegory such as Le Crocodile combine a political, social, and poetic vision of the war, and to what effect? Within this "poëme hiéroglyphique et baroque, ${ }^{30}$ snubbed on account of its outlandish excesses, lie perhaps the most searing indictment of intellectual and moral irresponsibility and the most hopeful expectations about regeneration written just before the onset of the Terror by any of its witnesses. Yet one fellow poet-philosopher across the Channel was writing, at the same time, an equally eclectic work, featuring "the sneaking serpent," mixing

28 "Le Crocodile, en paraissant, n'a pas fait une grande sensation, parce que les bases sur lesquelles il repose sont si loin des notions reçues qu'on ne l'a pas entendu. Dans le vrai, il est plein de négligences, et il se sent de l'envie démesurée qu'avait l'auteur d'en être débarrassé. Il n'en est pas moins sûr qu'avec une lessive de plus, il aurait pu devenir un bijou, tant le fond prêtait et était susceptible de fournir de l'extraordinaire, du doux, du piquant, enfin de tout ce qu'on aurait voulu. Cela sera réservé pour une seconde édition si toutefois elle se fait jamais, ce dont je doute." Saint-Martin, Mon Portrait, 394.

29 Robert Amadou, preface to Le Crocodile, 24. See also Jacques-Chaquin [Jacques-Lefèvre], "Le Crocodile de Louis-Claude de Saint-Martin: le Paris fantastique d'une Révolution figurée," in Studia Latomorum et Historica. Hommages à Daniel Ligou, ed. Charles Porset (Paris: ChampionSlatkine, 1998), 183-202; and Sekrecka, 185-90.

30 Sainte-Beuve criticized the epic prose poem as "une plaisanterie lourde le plus souvent et du plus mauvais goût ... Le rire, en général, va peu aux mystiques ... Saint-Martin ne gagne rien à s'approcher du genre de son compatriote Rabelais" (210). 
prose and verse, satire and paradox, epigrams and visions: William Blake's Marriage of Heaven and Hell offers surprising parallels with $\mathrm{Le}$ Crocodile, with regard to its heterogeneous form but also context, source, and substance. Inspired by the French Revolution with which Blake sympathized, Marriage of Heaven and Hell is filled with references to Boehme as well as a critique of Swedenbörg in the same disillusioned vein as Saint-Martin's. Like the "philosophe inconnu," Blake promoted a spiritual vision that condemned materialism (the Newtonian world and Locke's empiricism), rejected priesthood and dogma, but extolled energy and desire. In the absence of firm evidence, one can only suggest that Saint-Martin be included in Jon Mee's assessment that "Blake's prophetic radicalism has features in common with a whole range of texts produced from a broader culture of enthusiasm." 31

Saint-Martin recorded precisely his completion of Le Crocodile. “C'est le mardi 7 août 1792 à une heure après midi que j'ay fini le Crocodile, dans le petit cabinet de mon appartement de Petit-Bourg, donnant sur la Seine; c'est dans cette même semaine que la Révolution française a fait un si grand pas, puisque c'est le 10 août qu'arriva la grande bagarre à Paris où je m'étais rendu le 8 ... Le Crocodile a reçu depuis lors de nombreuses additions, mais le fonds est le même que lorsqu'il fut fini à l'époque ci-dessus." ${ }^{2}$ This diary entry raises more questions regarding the connection between the text and its historical context than it answers. Why the surprisingly naive euphemism of "la grande bagarre" to refer to the 10 August uprising that brought the king to prison three days later and signalled the foundation of the Republic? What were the numerous additions, which he mentions, made to the text between its completion during this

31 Jon Mee, Dangerous Enthusiasm: William Blake and the Culture of Radicalism in the 1790s (Oxford: Oxford University Press, 1992), 51. Had Saint-Martin heard about Blake during his time in London (January-July 1787)? Was Blake aware of Saint-Martin's Des Erreurs et friends or perhaps and L'Homme de désir (1790), directly or indirectly through his circle of friends or perhaps Johnson's Analytical Review? Though further research is necessary to ascertain textual references linking the two authors, theirs were kindred spirits participating in a "radical Enlightenment." Mee argues that "bricolage" (the incorporation of elements from various discourses) is "a striking feature of the organization of Blake's poetry, a feature shared by many whose writing responded to and was shaped by the Revolution controversy" (10). The circulation of Saint-Martin's works in Europe suggests that Blake's 1790 s, see Stuart Art and Science (Norman: University Blake and the Impossible History of the Oklahoma Press, 1998); and Saree Makdisi, William Blake and the Impossible History of the 1790s (Chicago and London: University of Chicago
Press, 2003).

32 Saint-Martin, Mon Portrait, 315. 
momentous August in 1792 and its eventual publication in 1799? Despite Saint-Martin's claim that the substance of Le Crocodile has not changed, how did the "Great Terror" from 5 September 1793 to 27 July 1794 affect his revisions? What about Bonaparte's Egyptian expedition of 1798, his victory in the battle of the Pyramids, and the bloody massacre of the Jaffa prisoners? ${ }^{33}$

The very nature of allegory prevents the reader from identifying its exact referent, multiplying instead interpretative layers that fluctuate with time. Benjamin, in his study of the German Baroque drama, linked allegory with ruins and the fragmentation of reality. Benjamin famously contrasted the symbol, which offers a glimpse of nature's transfigured face, to allegory displaying history's facies hippocratica, that is, its death's head: "This is the heart of the allegorical way of seeing, of the baroque, secular explanation of history as the Passion of the world; its importance resides solely in the stations of its decline." ${ }^{34}$ Allegory conveys historicity and temporality, whereas the symbol encapsulates immediacy and makes it seem eternal. A symbol functions like a revelation, a lightning flash, whereas allegory is always a construction. A symbol fuses the signifier and signified, whereas allegory separates them. As Todorov explained, "the symbol is, allegory signifies." ${ }^{35}$ Saint-Martin built the allegorical framework most relevant to the period 1789-99, ten extraordinary years of destructive as well as constructive warfare that changed the course of every reader's life and French history. Yet, as Furet writes, "il existe ... une histoire de l'histoire de la Terreur, liée au vicissitudes de l'histoire politique française depuis deux cents ans," ${ }^{36}$ thus making it impossible and unwise to give a definitive, "eternal" meaning to the revolutionary Terror. Whatever revisions Saint-Martin may have made to his prose poem until 1799, his allegory encourages readers to work within their own temporality and historicity to build transitory meanings.

33 Chateaubriand viewed Napoleon's Egyptian campaign politically as a drastic, imperialist turn, and aesthetically as an "epic poem" aggrandizing a life story: "à peine a-t-il [Bonaparte] mis l'Italie sous ses pieds, qu'il paraît en Egypte; épisode romanesque dont il agrandit sa vie réelle. Comme Charlemagne, il attache une épopée à son histoire." François-René de Chateaubriand, Mémoires d'outre-tombe, 2 vols. (Paris: Gallimard, 1951), 1:711.

34 Benjamin, 166. "Whereas in the symbol destruction is idealized and the transfigured face of nature is fleetingly revealed in the light of redemption, in allegory the observer is confronted with the faciès hippocratica of history as a petrified, primordial landscape. Everything about history that, from the very beginning, has been untimely, sorrowful, unsuccessful, is expressed in a face-or rather in a death's head" (Benjamin, 166). Benjamin considered Jacob Boehme "one of the greatest allegorists" (201).

35 Tzvetan Todorov, Théories du symbole (Paris: Seuil, 1977), 251.

36 François Furet, "Terreur," in Dictionnaire critique de la Révolution française, ed. François Furet and Mona Ozouf (Paris: Flammarion, 1988), 165. 
For most critics, Le Crocodile's happy ending trumps the violent revolutionary context during which it was composed and revised, emphasizing instead the context of millenarianism and its hopeful expectations: ${ }^{37}$ the strength and reach of Saint-Martin's message not to forsake the spiritual in favour of the rational effaces all traces of disappointment or disillusion that the author may have experienced as the Terror unfolded. To the contrary, I wish to underline that Saint-Martin's prophetic rhetoric exhibits and represses the experience of violence and death. Blanchot's meditation on writing and death captures Saint-Martin's own repressed confrontation with death (his own, that of friends, and that of countless victims) in the years when he wrote and revised his epic prose poem: "Écrire, c'est ne plus mettre au futur la mort toujours déjà passée, mais accepter de la subir sans la rendre présente et sans se rendre présent à elle, savoir qu'elle a eu lieu, bien qu'elle n'ait pas été éprouvée, et la reconnaître dans l'oubli qu'elle laisse et dont les traces qui s'effacent appellent à s'excepter de l'ordre cosmique, là où le désastre rend le réel impossible et le désir indésirable." ${ }^{38} \mathrm{Le}$ Crocodile, as allegory, dissolves all suspension of disbelief. The reader's task is not to empathize, as was customary with contemporary sentimental novels, but to decipher. Names are encrypted: the main character is Sédir, an anagram for "désir"; the protagonist Éléazar, a Spanish Jew (like Pasqually), has a Hebrew name revealing his connection with God; Rachel, his daughter in the story, is a biblical figure; the benevolent Madame Jof represents "la Foi"; her husband, the jewel maker, bears all the attributes of Jesus. In the opposite camp of evil forces, nefarious geniuses appear alongside three agents of the crocodile, conspirators named "la femme de poids," who dresses like a man; "le grand homme sec," closely resembling Cagliostro; and the shouting and violent general Roson (anagram of "sonore"), who leads the evil rebellion. In choosing a crocodile to embody the forces of evil, Saint-Martin subverted a sacred Egyptian symbol into a parodic reference to the rites of supposedly Egyptian origins introduced in France by Cagliostro. ${ }^{39}$ The crocodile, which bursts from under ground one day in Paris, proclaims itself the expression of universal matter: its objectives are to corrupt human intelligence through lies and confusion, and to

37 Simone Rihouët-Coroze, "Analyse du Crocodile," in Le Crocodile, 59-61.

38 Blanchot, 108-9.

39 For an analysis decrypting Masonic symbolism, see Jean-Louis Ricard, Étude sur "Le Crocodile, ou la guerre du bien et du mal" de Louis-Claude de Saint-Martin (Paris: Centre international de Recherches et d'Études Martinistes, 1996). 
foment human extermination through self-destruction. The war between good and evil forces is fought through several battles, each allegorical as well. ${ }^{40}$

The description of revolutionary Paris borrows a few realist touches (topographical, for instance), but Saint-Martin's goal was not historical; his story is not about facts but meaning. Thus the shortage of wheat, people's hunger, and the spreading famine, while reflecting the food crisis actually suffered by Parisians, illustrate as well people's hunger for knowledge and for some understanding of the confusing events rocking the capital. Saint-Martin translated the power of revolutionary crowds into images of warlike column formation, and its anarchical impulse into a torrent flowing into the streets. One scene briefly sketched the confusing heterogeneity of the crowd: "On voyait donc l'ennemi sortir par colonnes des différentes rues de la ville et des faubourgs, comme autant de torrents, et venir se jeter en foule vers l'endroit où se trouvait le plus d'espace. Chaudronniers, maîtres à danser, cuisiniers, ramoneurs, fiacres, poètes, tout était pêle-mêle dans cette horrible confusion" (114). This humorously eclectic enumeration juxtaposed with hints of horror is a good example of the text's destabilizing effect, always working against readers' expectations. Similarly, in a canto titled "Fureurs du peuple contre le contrôleur général," a hungry people, looking for a culprit, storm the contrôleur général's house to punish him for his mismanagement. But the dramatic, potentially bloody outburst hits against six alexandrine lines mimicking the contrôleur's insouciance:

Le peuple, que la faim travaille de plus en plus, et que les discours des savants ne soulagent point, cherche enfin à connaître l'auteur de tous ces désastres; ou plutôt il cherche à assouvir sur lui sa vengeance ... On court en foule à son hôtel, qu'on entoure; on enfonce la porte, et l'on entre: que trouve-t-on?

Dans ce temps désastreux, dans ce temps d'indigence,

Où chacun, malgré soi, fait entière abstinence,

Le ministre est à table, entouré de perdrix,

De pain frais, de gâteaux, de vins les plus exquis ;

Et pour mieux oublier la misère publique,

Il appelle au festin le Dieu de la musique. (152, emphasis added)

40 See Rihouët-Coroze, 29-61. 
As the text returns to prose, the crowd, "les furieux," resumes its destructive mission, yet its prey unexpectedly escapes and damages are only material (152). Saint-Martin's choice of words to describe the minister on the run is key: "Mais la terreur l'accompagnant partout, il croit voir à chaque instant tout Paris armé contre lui; et il est obligé de renoncer à prendre la moindre part à la lumière du jour: aussi n'a-t-on jamais su depuis ce qu'il était devenu" (152). Stylistically (verse vs prose) and semantically ("temps desastreux" vs "perdrix, pain frais, gâteaux, vins"; "terreur" vs "lumière"), the allegorical epic poem represents the insurgency at the same time as it contains its furor. Though this aesthetic effect might feel like an artifice, allegory is able here to signify the violence while keeping it at a distance. Moreover, the lilting alexandrines of times past surrender to the prose of revolutionary history, an emblematic victory.

Any reader of Le Crocodile will be struck, no doubt surprised, by the omission of blood and death in this war story. Does it cast SaintMartin as a pacifist, or perhaps an early proponent of non-violence? The author does not explicitly oppose war; violence, fighting, and armed conflicts appear but no bloodshed, and remarkably no death in Le Crocodile. ${ }^{41}$ Paris police lieutenant Sédir orders his troops to preserve life, and urges combat without killing: when they capture their enemies at the end of the story, they receive "ordre de ne leur faire aucun mal, jusqu'à ce que les lois aient décidé de leur sort” (242). Their fate is prison, not execution. Under Saint-Martin's pen, even the crocodile does not sacrifice life but temporarily suspends it, as when the monster swallows the two opposing armies at the beginning, then throws them up so violently at the end that they find themselves in the skies among stars and planets. There, the two armies resume their fighting as mighty cosmic spheres that collide violently. Instead of exploding as one might expect, they reciprocally bounce off one another. Drawn back to earth, the two armies eventually reconcile, becoming "une famille de frères" (243). As for the vanquished crocodile, he is engulfed back into the earth, to be more tightly pinned under one of Egypt's pyramids. In keeping with his stance against the

41 The subtitle, itself a metatextual parody, mocks conventional genres (picaresque, sentimental, and epic) and prepares readers to enter a fantastic epic where no blood is spilled: "Poëme épico magique en 102 chants ... Dans lequel il y a de longs voyages, sans accidents qui soient mortels; un peu d'amour, sans aucune de ses fureurs; de grandes batailles, sans une goutte de sang répandu; quelques instructions, sans le bonnet de docteur; et qui, parce qu'il renferme de la prose et des vers, pourraient bien en effet n'être ni en vers, ni en prose" (emphasis added). Similarly, Blake's unfinished poem The French Revolution has no victims. 
death penalty, Saint-Martin consistently refused to portray death as punishment, shunning historical evidence and Gothic pyrotechnics, to embed the more subtle conviction that neither evil nor goodness ever completely disappears. Tellingly, the verbs conveying the outcome of the various fights in the story deploy the semantic field of the fall, such as "renverser à terre" and "culbuter." When malevolent geniuses try to massacre Éléazar, they manage to make him fall, but when he eventually recovers his strength, "il se redresse sur ses pieds" (208-10). Saint-Martin's characters escape the dichotomy of invincible superheroes and hapless victims, reflecting his belief that people could rise from their fallen station in life if they turned to faith and inner strength. Saint-Martin always allows the option of spiritual regeneration, and when people stumble because of their vices, they retain their virtues and always have the potential for redemption: "c'est ainsi que si le premier homme coupable fut englouti dans un abîme avec ses vices, il y fut englouti aussi avec ses vertus, et que l'éternelle raison des choses trouva moyen par là de faire filtrer jusqu'à lui un universel régulateur, qui le remit dans les voies passagères de la rectification" (232). In a manner as surprising as in Lettre à un ami, Saint-Martin did not frame the revolutionary conflict as a bloody class confrontation, the Third Estate opposing aristocrats and the clergy. Nor did he fictionalize in any way the political battle between the Girondin and Jacobin factions as he could have before publishing the story in 1799. As in his essay, "the unknown philosopher" painted a completely alternative picture to sociopolitical and historical representations of the revolutionary crisis, offering instead a vision of apocalyptic spiritual and ethical transformation. ${ }^{42}$

Similar revolutionary crises are the source of the numerous national wars mentioned in the course of the allegory, each historical occurrence being linked to the crocodile's evil momentum, evidenced in his speech to the Parisians and the discourse and behaviour of the captives in his entrails. For example, in his belly, figures play a political game of cards wherein each card stands for a kingdoman explanation for the perpetual shuffling of empires (178). SaintMartin suspended the narrative from canto 30 to canto 35 in order

42 Saint-Martin's residence in Strasbourg then Amboise, away from the Parisian theatre of revolutionary events, might account for his political distance (although he was affected by the imprisonment of some of his friends), leading him to focus on the origins and longterm implications of 1789 rather than on ideological battles. 
to transcribe the "discours scientifique du crocodile," a lengthy chronicle of the reptile's involvement in historical events, a parallel history to the official version, revealing the agency of evil at work from the beginnings of the world and throughout time. ${ }^{43}$ But the point of Saint-Martin's allegory lies beyond the conviction that evil originates war; it concerns his answer to the difficult question of the origins of evil itself. Where does evil come from? Though SaintMartin adhered to the Christian belief in humanity's original fall, the text implies a concomitant origin as well as responsibility: evil grows within us. The principle that derives from this inner proclivity is that freedom means the capacity to choose between good and evil. Several prototypes illustrate this choice. On the positive side, the historical figure of Las Casas and the fictional characters Rachel and Ourdeck choose to follow benevolent influences and internal predilection. By contrast, the rebel general Roson and "le grand homme sec" exercised their freedom in favour of evil impulses, opposing their heritage of goodness: in a moment of remorse "le grand homme sec" reveals that his mother, who possessed "les lumières les plus sublimes, les vertus les plus rares et les dons les plus extraordinaires," tried to steer him onto the path of wisdom and virtue, but he chose to follow other masters and let himself be subjugated (155-56).$^{44}$ As for Roson, Éléazar laments the criminal and disorderly life that this former acquaintance chose to lead, driven by his "caractère altier et audacieux" (101). The crucial definition of freedom as a choice between good and evil mirrors the striking metaphor of the "carte noire" given by aerial enemies to their delegate in order to exterminate Éléazar (212). The "carte noire" is the obverse of the "carte blanche," the French idiomatic phrase synonymous with free choice or doing what one pleases: as one exercises freedom, the options always include a black card, because freedom for Saint-

43 Saint-Martin gives voice to the evil crocodile for the same reason that Blake transcribes "the voice of the devil" in The Marriage of Heaven and Hell-"the Proverbs of Hell shew the nature of Infernal wisdom better than any description of buildings or garments." William Blake, The Complete Poetry and Prose of William Blake, ed. David V. Erdman (Berkeley: University of California Press, 1982), 35. Charles Baudelaire also let the devil speak in his prose poem "Le Joueur généreux," yet another allegory of evil with hard to verify yet plausible connections with Saint-Martin. Blake's subversive inversion of good and evil seems much closer to Baudelaire's own understanding of evil. Baudelaire, Le Spleen de Paris. Petits poèmes en prose, in Euvres completes (Paris: Gallimard, 1976).

44 Spiritual fulfilment, however, still eludes him: "Au lieu de la paix qu'ils [ces maîtres] m'avaient promise, je n'ai que du trouble; et au lieu des lumières que j'ai cru pouvoir acquérir par des voies qui m'ont été présentées comme plus commodes, je n'ai qu'une incertitude universelle" (156). 
Martin is not a blank slate but a choice between the negative and the positive, darkness and light.

Nations face similar choices, but with the added perverse effect that evil begets evil, or, in Saint-Martin's metaphor, that the crocodile lends for the sake of usury, as was the case with Spain's murderous conquest of the Americas: "les Espagnols trouvèrent la mort dans leurs plaisirs en Amérique, après y avoir cherché l'or dans le sang de ses habitants, et chez eux je leur ai donné l'Inquisition, qui est comme l'abrégé et l'élixir de toutes mes industries" (132). SaintMartin was less ambiguous in his critique of colonialism than most of his contemporaries, but his position was even more original in its appreciation of colonialism as the onset of globalism, with the inherent danger of explosive conflicts in a world interconnected by relationships of power and dominance, as in a chess game: "le profit que j'ai fait à la découverte des Indes et de l'Amérique, c'est qu'actuellement il ne me faut qu'une allumette pour embraser le globe. Ainsi la politique, sur toute la terre, est devenue, par mon ministère, comme une partie d'échecs qui commence toujours et qui ne peut plus finir, parce que les puissances qui en forment les diverses pièces, peuvent bien se prendre les unes les autres, mais elles ne peuvent me prendre moi, qui en suis roi, et elles ne savent pas me faire mat; aussi les génies, mes adversaires, sont-ils entièrement déroutés aujourd'hui" (132). Thus, the crocodile strikes back: imperialism bears violent (terrorist?) fruit, which we do not yet know how to checkmate.

\section{Taking Aim}

In addition to wars, the manifestation of evil upon which the allegorical epic insists the most concerns the distortion of truth. Whereas Saint-Martin primarily targeted the Church in his Lettre $\grave{a}$ un ami, his prose poem focuses on two sets of equally manipulative characters: magicians and scholars. Saint-Martin's denunciation of false prophets, such as Cagliostro, placed him at the heart of the Enlightenment's critique of abusers of faith, whether they plied their mystification as clergy members or phony clairvoyants. But, as we will see, the relentless accusations directed against scholars, scientists, philosophers, and academicians of all stripes gave Saint-Martin his counter-Enlightenment reputation. Within the framework of the allegory, I propose to clarify why Saint-Martin blamed his learned 
compatriots, and what link he established between their work and revolutionary events. In lieu of an oversimplified classification as "anti-Lumières," a nuanced reading can offer a more progressive orientation for a "philosophe inconnu" whose priorities regarding truth and knowledge mirror the Enlightenment's credo after all. By nature heavy-handed, allegory emphasized scholarship's blind spots and shortcomings, thereby raising concerns and warnings reverberating to this day.

Éléazar warns the police chief Sédir that "le grand homme sec" from Egypt (alias Cagliostro) is the state's most terrible enemy (108). This shady individual admits that he "rules in a zero," hence the need to capture and retain people's minds: "Parce que comme je ne règne que dans un zéro, je fais ce que je peux pour retenir les hommes dans mon royaume" (160). But his magic is a lie: "Il soutient, tant qu'il peut, la révolte, par les moyens qui lui sont connus; il souffle dans les conjurés l'esprit de vertige ... [mais] il ne peut conduire aucune entreprise jusqu'à un heureux terme, parce qu'il ne connaît pas ses propres correspondances avec la porte de la nature, et quand il veut en essayer la clef, qui en effet se trouve partout, il la tourne toujours à contre-sens" (109). Instead of unlocking nature's mysteries, this nefarious character turns the key the wrong way, to confuse scholars' minds, to destroy their books, starve Parisians, and entice them to crime (157). Beyond the imposture perpetrated by Cagliostro and the like, Saint-Martin seems to be warning his readers against the power of religious sects to blind their flocks: "Ce qui le rend si à craindre, c'est qu'au moyen de quelques fausses lumières et de quelques puissances encore plus pernicieuses, il fascine les yeux de ses disciples, et leur ferme l'entrée aux lumières véritables" (108). In another episode, deep in the crocodile's entrails, the reader sees alchemists promising treasures, "pendant que la seule alchimie et les seuls trésors qui soient véritablement utiles pour nous, c'est la transmutation ou le renouvellement de notre être" (226). Other creatures dwelling inside the beast include fanatics, who massacre their fellow beings "au nom d'un Dieu de paix," and writers, who do not pursue truth but vainglory $(227,226)$.

Like his agent "le grand homme sec," the crocodile seeks to distort truth, but the animal represents an even more insidious threat. Its tail pinned under one of Egypt's pyramids, this reptile can distend itself to reach the four corners of the globe, as well as metamorphose into 
different forms. In the genealogy of evil that he chronicles before a dumbfounded crowd of Parisians and scholars, the crocodile particularly rejoices at the help he received from the invention of the printing press and the swift dissemination of books under the reign of Louis Xv, as useful to this current destructive ambition as cannon powder had been in the previous century. ${ }^{45}$ Although lamenting a lack of funding, which restricted the range of its circulation, the crocodile singles out Diderot's famous Encyclopédie for how it might have promoted and expanded his reign, namely the reign of matter and materialism: "quels fruits n'aurais-je pas retirés de cette Encyclopédie animée, qui, pullulant sans cesse, eût successivement étendu mon règne sur toute la terre !" (134). Exaggerating the spread of noxious or empty works and their authors' misguided scholarship, the narrative introduces two more allegorical scenarios, the plague of books and the sciences held in captivity, thus targeting the core of what is usually considered Enlightenment's success: its formidable philosophical and scientific advances.

One of the most sensational episodes illustrates the ineptitude and impotence of scholars when confronted with a catastrophic threat requiring immediate action. When an academic decree orders them to search all libraries to explain the apparition of the crocodile, "une plaie tomba subitement sur tous les livres," a mysterious humidity turns all books, all over France, into a gray, soft mush (136). At the same time, a legion of women looking like maids and wet nurses appears in every scholarly meeting place. Armed with spoons, they feed the mushy paste to the voracious scholars. The scholars react, says the narrator, "avec une telle confusion de pensées et de langage, que la tour de Babel, en comparaison, était un soleil de clarté; parce que tous parlaient ensemble, et que chacun parlait de toutes les sciences à la fois" (137). A member of the Academy, who may have eaten more than his colleagues, begins an apparently incoherent speech ("Une fureur de paroles, de citations et d'interprétations s'empare de lui" [138]): for a dozen pages, the reader is treated to a Rabelaisian parody of scholarly discourse, merging the scientific

45 Blake's third "Memorable Fancy" in The Marriage of Heaven and Hell mysteriously begins with a "Printing House in Hell," where the poet sees "the method in which knowledge is transmitted from generation to generation" (40). Blake's imagery of caves, dragons, and vipers in association with books and libraries bears an uncanny resemblance to Saint-Martin's, though Blake's netherworld allegorizes the creative process while Saint-Martin deplores the overproduction of books. The limited circulation of Blake's work makes it unlikely that Saint-Martin knew The Marriage of Heaven and Hell. 
and literary in a burlesque collage of references. Although language seems to collapse into gibberish, the narrator has warned that we may glimpse truth amid the academician's ramblings. For example, the latter interjects that man's soul, though immortal, has become a night moth consumed by anxiety (142). He describes three afflictions impeding action, three metaphoric obstacles to eliminating the beast and cleansing the mirror of truth: ${ }^{46}$ people are sleepwalking (the crocodile keeps their heads under their wings- "la tête sous l'aile"); philosophers are babbling; and scientists are blind. Several episodes in the story parody the scientific obsession with description and measurement. Naturalists, for instance, only describe the visible in nature and fail to satisfy our need to understand the invisible (104). Contrasting the obsession to measure sound with the mystery of music, the academician asks whether, "au lieu de toiser le son comme ont fait les savants, n'auraient-ils pas dû plutôt nous enseigner ce que c'est que le son, et nous montrer que puisqu'il ne se forme que par des brisures, il nous serait possible de parvenir jusqu'à sa demeure, en suivant les traces de ces mêmes brisures? Néanmoins avec les seuls moyens qui nous sont connus, nous voyons opérer différentes merveilles et différents effets de musique; nous exprimons la gaieté, la tristesse, l'amour, la terreur, la haine, une mouche qui vole, un hollandais qui fume sa pipe" (146). ${ }^{47}$ Whereas the search for origins should prevail, scientists have hidden nature behind abstract scaffolding (225). We have learned that the crocodile's belly holds a menagerie of phony scholars (housed in chicken pens), who have mutilated the sciences and deceived men; the crocodile employs them to perpetrate lies (177). As he boasted in his scientific discourse upon his appearance in Paris: "j'ai fait professer aux philosophes de ce siècle toutes ces doctrines qui ont appris aux hommes que tout n'était rien; que les corps pensaient, et que la pensée ne pensait point; que l'on avait pas besoin de recourir à un sens moral pour expliquer l'homme; mais qu'il fallait seulement lui apprendre à faire des idées" (133). The doctrines of materialism, sensualism,

46 "Un philosophe inconnu nous a dit que ... nous désirerions de connaître la vérité, et que nous ne faisons rien pour en nettoyer le miroir; que c'est comme si nous prétendions voir clair au travers de nos vitres crasseuses et couvertes de poussière et d'ordures" (145, emphasis added).

47 The sentence progresses from general emotions stirred by music to two whimsical cameos of a fluttering insect and a pipe-smoking Dutchman, briefly conjuring up poetic correspondences between visual tableaux and music that seem to anticipate a Baudelairian aesthetics. Space does not permit me to develop here Saint-Martin's law of correspondences, an essential theme throughout his work and Le Crocodile in particular. 
atheism, and encyclopédisme are conflated in a systematic accusation (void of nuance), confirming Robert Amadou's verdict on "le dessein principal du livre: dénoncer les erreurs de la pensée moderne." ${ }^{48}$ A particularly self-deprecating comment in the mouth of an academician encapsulates Saint-Martin's illuminist view that his century was extinguishing the Light: "Car nous sommes un peu semblables aux rats, qui s'introduisent dans les temples, qui y boivent l'huile des lampes, et détruisent par là la lumière qu'elles pouvaient répandre; et puis nous disons qu'on n'y voit pas clair" (145). Yet, this also grants scholars the power of self-criticism, opening the door to reform. ${ }^{49}$ Saint-Martin, while he was indeed combatting the eighteenth century in its materialist naïveté, also borrowed from Enlightenment philosophes. ${ }^{50}$ Confining his position to an antimodern, anti-rational stance counter to the Enlightenment's thrust (even if the parody at work in the allegory might encourage it) does not represent his contribution to the debate on modernity. Insofar as he adopted the same discursive pugnacity as the philosophes, he participated in the dynamic of the Enlightenment to escape what Kant famously defined as "un état de minorité."51

Silence is recommended to the wise few. One character's most hopeful academic experience is the revelation of an academic "chaire de silence" in the imaginary city of Atalante. The evil effects of misguided scholarship are one of the primary concerns of the allegory. Did the obsession with rationality lead to revolutionary excesses? Saint-Martin's more subtle answer is that alienation results from the "faux usage de la liberté de l'homme" and induces violence (225). One of allegory's strongest assets is the ability to reveal and conceal simultaneously, as evident in the evocation of Atalante. Among the persons frozen in time whom Ourdeck discovers, their words inscribed above their heads, are a preacher in a temple and a hierophant in his cave, located in "rue des Singes." The visitor Ourdeck realizes that the preacher was a hypocrite whose doublespeak he can see as a "double courant de paroles" (203), a stream of words he follows through the littered and narrowing "rue des

48 Amadou, preface to Le Crocodile, 23.

49 For example, the same self-critical academician admits that he and his colleagues are probably not so much against the name and idea of God as against its "teinte capucineuse," from "capucin," the religious order whose corruption has tainted the sacred name (149).

50 See Sekrecka, 45.

51 Immanuel Kant, “Réponse à la question 'Qu'est-ce que les Lumières?'”(1784), in CEuvres philosophiques, 2 vols. (Paris: Gallimard, 1985), 2:209-17. 
Singes" to the hierophant's chair in an underground temple of symbolic proportions and ritual objects, including chained iron monkeys on an altar. A horrified Ourdeck understands that the hierophant's goal consisted in "faire anéantir l'ordre de toutes choses, et d'établir à sa place un ordre fictif, qui ne fût qu'une fausse figure de la vérité." As soon as Ourdeck reads that "un homme saint et respectable" (205) will overthrow the scheme of these enemies, he desires to know his identity so much that, as the name Éléazar appears, it brings to life the two iron monkeys, who in a few minutes multiply, devour the assembled disciples and the hierophant (after plucking out his eyes), then devour one another without leaving traces. ${ }^{52}$ Such an extraordinary scene is open to interpretation, for the hierophant and his initiated could equally represent priests, black magicians, rationalists, or revolutionary ideologues, with the latter's reciprocal extermination during the Terror a possible referent for this suggestive, cataclysmic ending.

\section{Prevailing Virtues}

If the Apocalypse according to Saint-Martin leads eventually to redemption, credit must be given to the forces of goodness and their pacific weapons. Wisdom, desire, faith, and knowledge constitute four essential virtues that help the characters triumph over the crocodile. Éléazar, "le digne Israélite" who often cites Solomon, embodies wisdom. Particularly noteworthy is the clue that Éléazar was formerly an intimate friend of an Arab scholar "de la race des Ommiades réfugiés en Espagne, depuis l'usurpation des Abbassides" 53 and that one of his Arab friend's ancestors had known Las Casas, who transmitted to him secret powers. The text insists on the essential confluence

52 Striking similarities exist between this episode and the end of Blake's fourth "Memorable Fancy" in the Marriage of Heaven and Hell, where the poet "exposes theology in a frightening vision of intellectual cannibalism." Harold Bloom, Commentary, in The Complete Poetry and Prose of William Blake, 899. "In it [one of seven brick houses] were a number of monkeys, baboons, and all of that species chaind by the middle, grinning and snatching at one another, but witheld by the shortness of their chains: however I saw that they sometimes grew numerous, and then the weak were caught by the strong and with a grinning aspect, first coupled with and then devourd, by plucking off first one limb and then another till the body was left a helpless trunk. This after grinning and kissing it with seeming fondness they devoured too; and here and there I saw one savourily picking the flesh off of his own tail; as the stench terribly annoyed us both we went into the mill, and I in my hand brought the skeleton of a body, which in the mill was Aristotle's Analytics" (42).

53 “Concernant les 'Ommiades,' l'encyclopédie des Arts et Métiers de Diderot ... précise que c'est le nom attribué aux princes d'une dynastie arabe, qui depuis l'an 32 de l'égire ont possédé le Khalifat pendant 91 ans, ils descendent d'Ommiah." Ricard, 25. 
of Hebrew, Arab, and Christian heritage within the story's most sacred and spiritual protagonist, whose mysterious magical powder was invented by the Arab scholar. ${ }^{54}$ Éléazar's wisdom rests in this triple religious and cultural heritage, a significant message on SaintMartin's part concerning his belief in the peaceful coexistence and reciprocal enrichment of faiths and cultures. ${ }^{55}$

Desire, incarnated by Sédir, is Saint-Martin's code word throughout his mystical writings to urge the reader to seek truth. Desire is expression as well as action, the aspiration to be intimate with and understand the human spirit. When the mysterious jewel maker/invisible man proclaims, "Sédir, levez-vous" (233), Sédir rises to defeat the monster, free the sciences, thus returning peace and abundance to Paris. The traveller Ourdeck, who courageously volunteered to defend Paris, embodies another manifestation of desire as a slow process of initiation and awakening for those who were initially sceptical. Tellingly, the antepenultimate canto, titled "Les désirs d'Ourdeck accomplis" (canto 101), celebrates the end of Ourdeck's journey towards faith and knowledge. As a reward, "le pouvoir magique" of his desire draws Rachel near him, happily ending the story with their marriage celebration (245).

Madame Jof, as the incarnation of faith, sustained and supported Ourdeck during his trials. Faith offers the possibility of belief in higher truths, invisible to the naked eye, for “ce n'est pas dans les limites de notre vue corporelle que sont renfermées toutes nos connaissances" (45). Her ubiquitous powers make her "une véritable cosmopolite" (87), another reminder that the spiritual trumps cultural and religious particularisms. The Society of Independents, which she heads, is a virtual assembly whose members communicate and see one another regardless of distance (87). Her speech to the Society fellows didactically rephrases the various points illustrated by the story: Paris is punished by shortages and famine because her citizens ignored a more essential and spiritual hunger; prodigies have dazzled and scared them because Parisian scholars and doctors neither are searching for genuine knowledge nor have the right minds to do so; they can contemplate the universe's marvels but not

54 Éléazar confides to Sédir: "Vous voyez ... quels sont les étonnants avantages du secret que mon Arabe m'a confiés; je ne veux plus vous en faire un mystère. Ce secret est en vous comme il est en moi et dans tous les hommes" (219).

55 Éléazar also represents tolerance, as evidenced by his forgiving of his Christian friend's betrayal, who denounced him as a Jew and sorcerer to the Inquisition (102-3). 
unlock the secret of its existence. ${ }^{56}$ Madame Jof laments atheists, who do not recognize a divine principle, and false prophets, but reserves her harshest blame for priests (90). She remarks that writers who are the friends of truth have had to hide it under emblems and allegories "tant ils craignaient de la profaner et de l'exposer à la prostitution des méchants. C'est pourquoi, enfin, si l'on s'arrête aux cadres quelque fois singuliers de leurs écrits, et si l'on ne scrute pas jusqu'à la racine même de tout ce qu'ils exposent, et qui n'est autre chose que le malheureux état de l'homme dégradé, on ne peut pas les juger avec justesse; car ils gémissent grandement d'être ainsi obligés de se contraindre et de se taire" (90)..$^{57}$ The reason behind Saint-Martin's hermetic fiction and its singular allegorical framework is revealed.

\section{The Fate of the Allegory}

The ill-received Le Crocodile has suffered from comparison with Saint-Martin's most acclaimed work, L'Homme de désir, published in 1790 , a year after his enthusiastic discovery of Boehme's writings. ${ }^{58}$ Speaking in lyrical prose stanzas, "l'homme de désir" heralds the poetic creative power and prophetic mission of men and women. Today, excerpts are included in poetry anthologies, ${ }^{59}$ and it is the only work by Saint-Martin to be found in a French bookstore, albeit in the esoteric section. In a retrospective self-critique, Saint-Martin seemed to pitch Le Crocodile against L'Homme de désir.

J'ai toujours eu devant les yeux les ennemis à quij'avais affaire, les philosophes; comme ils n'ont opposé contre la vérité que des raisonnements froids et secs puisés dans l'ordre des choses matérielles, je me suis cru obligé de

56 “La plupart d'entre eux ne s'attachent qu'à disséquer l'écorce de la nature, à en mesurer, peser et nombrer toutes les molécules, et tentent, en insensés, la conquête fixe et complète de tout ce qui entre dans la composition de l'univers; comme si cela leur était possible, à la manière dont ils s'y prennent" (88).

57 For another important reference to the use of allegory, see the academician who gives up trying to explain the meaning of what is happening in Paris: "Ainsi sans m'arrêter à une explication qui ne nous instruirait pas, j'aime mieux à croire que le crocodile nous a tenu là un langage allégorique, conformément au goût de tous les anciens peuples chez qui il a voyagé, et que nous ne devons pas nous presser de fixer le sens de cette allégorie, tant que nous n'aurons pas plus d'éclaircissements" (148).

58 Saint-Martin, L'Homme de désir (1790; Monaco: Éditions du Rocher, 1994).

59 See Anthologie de la poésie française du dix-huitième siècle, ed. Michel Delon (Paris: Gallimard, 1997); and Catriona Seth, ed., "xvir" siècle," in Anthologie de la poésie française du xvü siècle, $X I X^{\prime}$ siècle, $X X^{\prime}$ siècle, ed. Martine Bercot, Michel Collot, and Catriona Seth (Paris: Gallimard, 2000), $1-436$. 
les combattre par les mêmes armes ... il faut de temps en temps, et par des passages vifs, élever leur pensée, les réchauffer assez pour qu'ils puissent euxmêmes percer plus aisément les objets qu'on leur présente et en retirer le fruit qu'on se propose. C'est à la vie d'aller chercher la vie. D'ailleurs il est des choses si sublimes, qu'on les déshonore, en les traitant avec le compas et la froide rigueur de la méthode. Il y a trop de cette méthode dans mes écrits, en comparaison du peu d'enthousiasme. Ce serait un plus grand danger peutêtre de n'y mettre que de l'enthousiasme et d'être faible dans la logique et les observations naturelles. Le point de perfection serait donc de réunir ces deux genres. C'est à quoi j'ai manqué jusqu'à présent. ${ }^{60}$

This admission of failure, however humble, has a lacuna. Saint-Martin does not invoke the historical event that prompted Le Crocodile in the first place: the Revolution. "L'enthousiasme" of L'Homme de désir (begun in 1787, finished in 1788, and published anonymously in 1790) is pre-Revolutionary, whereas the sprawling allegory of the war between good and evil was composed in 1792-the only fiction written by Saint-Martin after 1789 taking the Revolution as its source, as well as its subject. Could not allegory, in its supposed chilliness, be the sole available poetic device capable of confronting the systematic spirit and crimes of the Terror? Could the optimistic, enthusiastic poetic prose of L'Homme de désir convey fury, bloodshed, hunger, or academic obtuseness? Faced with the very modern question of how poetry confronts disaster, Saint-Martin chose allegory to convey what Blanchot calls "the jolt of rupture," to speak of absence, and to capture an event, imperfectly, without guaranteed meaning: "Pourquoi encore un livre, là où l'ébranlement de la rupture-l'une des formes du désastre-le dévaste? C'est que l'ordre du livre est nécessaire à ce qui lui manque, à l'absence qui se dérobe à lui: de même que le 'propre' de 'l'appropriation,' l'évènement où coappartiennent l'homme et l'être, s'abîme dans l'impropre de l'écriture qui échappe à la loi, à la trace, ainsi qu'au résultat d'un sens garanti." ${ }^{61}$

Le Crocodile addresses the fragmentation and destruction of the totality of history. ${ }^{62}$ The Revolution was a rupture, the Terror

60 Saint-Martin, "Du style en général," in EEuvres posthumes, 2 vols. (1807; Paris: Éditions rosicruciennes, 1986), 2:120-21. One might fruitfully contrast here Le Crocodile's lack of "l'enthousiasme" and verbosity with the concision and intensity of Blake's Marriage of Heaven and Hell, thanks in part to Blake's remarkable illuminated prints (such as the coiled Leviathan in a roiling sea), which saved Blake thousands of words.

61 Blanchot, 155 (emphasis added).

62 By contrast, the pre-revolutionary L'Homme de désir carries the hope of a true totality of experience, as suggested by its unifying symbolism. 
devastating. In their wake, Saint-Martin no longer chose symbolism but allegory. Paul de Man envisions symbolism and allegory as two discursive strategies available to the poets of modernity: he showed how the Romantic poets reacted to the rupture of modernity not only with the rhetorical choice of symbolism, to capture a lost unity for which they yearned, but also with allegories that represented and emphasized the experience of laceration. As Andrea Cesarini put it, allegory as "an alternative rhetorical procedure to symbolism ... renounces any nostalgic attempt at recomposition, is bitterly pessimistic, [and] lucidly catastrophic." ${ }^{63}$ Saint-Martin's theosophy should not be confined to its illuminist sphere but extended to encompass a darker, allegorical world, for each conveys wisdom, each offers a road to knowledge. ${ }^{64}$

University of Oregon

63 Andrea Cesarini, "The New System of Literary Modes in the Romantic Age," in The People's Voice: Essays on European Romanticism, ed. Andrea Ciccarelli, John C. Isbell, and Brian Nelson (Newark: University of Delaware Press, 1999), 14.

64 I wish to thank the anonymous readers at Eighteenth-Century Fiction for their helpful suggestions and the Early Modern Reading Group at the University of Oregon for their critical comments. 